Original Research Paper

\title{
FAKTOR-FAKTOR YANG MEMPENGARUHI KEDISIPLINAN PEGAWAI DI WILAYAH PUSKESMAS KAWATUNA KOTA PALU
}

\author{
${ }^{1}$ Prodi Kesehatan Masyarakat, FKM, Universitas Tadulako \\ ${ }^{2}$ Bagian Kebidanan, STIKes Widya Nusantara Palu \\ ${ }^{3}$ Prodi Keperawatan, Fakultas Kedokteran, Universitas Tadulako
}

${ }^{1}$ Vidyanto ${ }^{*},{ }^{2}$ A.Fahira Nur, ${ }^{2}$ Nur Eka Dyastuti, ${ }^{3}$ Andi Saifah, ${ }^{1}$ Nur Rahmawati

\section{Email Corresponding: \\ *vid.yanto@gmail.com}

Page : $75-86$

\section{Kata Kunci :}

Faktor yang mempengaruhi kedisiplinan

\section{Keywords:}

Factors that Influence Discipline

\section{Published by:}

Tadulako University,

Managed by Faculty of Medicine.

Email: healthytadulako@gmail.com Phone (WA): +6285242303103 Address:

Jalan Soekarno Hatta Km. 9. City of Palu, Central Sulawesi, Indonesia

\begin{abstract}
ABSTRAK
Kedisiplinan merupakan kesadaran dan kesediaan seseorang yang menaati semua peraturan dan norma-norma sosial yang berlaku. Berdasarkan studi pendahuluan Puskesmas Kawatuna merupakan salah satu puskesmas yang masih kurang kedisiplinannya mengenai waktu keterlambatan dan absensi. Puskesmas Kawatuna memiliki tenaga kesehatan dan non kesehatan sebanyak 64 orang. Lebih rincinya tenaga kesehatan PNS berjumlah 42 orang, yang terdiri dari tenaga kesehatan 40 orang, non kesehatan 2 orang. Pegawai tidak tetap (PTT) berjumlah 4 orang, tenaga kesehatan kontak berjumlah 5 orang. Dan tenaga kesehatan yang mengabdi berjumlah 13 orang. Didapatkan informasi bahwa pada tahun 2019 rekapitulasi absen diperoleh data absensi sebagian dari pegawai masih melakukan tindakan tidak disiplin, yaitu sekitar 18 dari 64 orang yang sering izin diluar dari tugas luar (TL), tugas belajar (TB) dan sering terlambat datang. Tujuan penelitian ini yaitu untuk mengetahui faktor-faktor yang mempengaruhi kedisiplinan pegawai di Puskesmas Kawatuna. Penelitian ini dilakukan di Puskesmas Kawatuna. Jenis penelitian kuantitatif dengan pendekatan Cross Sectional Study. Pengambilan sampel menggunakan metode total sampling. Pengumpulan data dilakukan menggunakan kuesioner dengan skala likert. Jumlah sampel 64 responden. Data yang diperoleh dianalisis secara deskriptif dengan menggunakan uji chi-square. Hasil penelitian menunjukan bahwa ada hubungan teladan pimpinan $(\rho=0,000)$, keadilan $(\rho=0,000)$, pengawasan melekat $(\rho=0,000)$, ketegasan $(\rho=0,012)$, hubungan kemanusiaan $(\rho=0,000)$, dengan kedisiplinan pegawai. Dan tidak ada hubungan sanksi hukuman dengan kedisiplinan $(\rho=0,227)$. Perlunya mengadakan pertemuan antara pimpinan dengan bawahan untuk membahas secara terbuka berbagai kendala yang berhubungan dengan kedisiplinan pegawai.
\end{abstract}

Discipline is the awareness and willingness of a person to obey all applicable social rules and norms. Based on preliminary research, Kawatuna Public Health Center is one of the health centers that lacks discipline regarding time delays and absences. Kawatuna Public Health Center has 64 health and non-health staff. More specifically, 42 civil servant health workers, consisting of 40 health workers, 2 non-health workers. There are 4 non-permanent employees, 5 contract health workers, and 13 health workers who serve. The Information was obtained that the recapitulation of attendance data for some of the employees who still took undisciplined actions in 2019, about 18 out of 64 people who often took permission outside of outside assignments, study assignments and often late arriving. This research aims to find out the factors that influence the discipline of employees at Kawatuna Public Health Center. It is a quantitative research type with a Cross-Sectional study approach. The number of samples was 64 respondents using the total sampling technique. Data were collected using a questionnaire with a Likert scale then analyzed descriptively using the chi-square test. The results of the research show that there is a relationship of leadership role $(\rho=0,000)$, justice $(\rho=0,000)$, inherent supervision $(\rho=0,000)$, assertiveness $(\rho=0.012)$, human relations $(\rho=0,000)$, with employee discipline 
and there is no relationship between penalties and discipline $(\rho=0.227)$. The need to hold meetings between leaders and subordinates to discuss openly various obstacles related to employee discipline.

\section{PENDAHULUAN}

Menurut Hasibuan (2011), kedisiplinan adalah fungsi operatif keenam dari Manajemen Sumber Daya Manusia. Kedisiplinan merupakan fungsi operatif Manajemen Sumber Daya Manusia yang terpenting karena semakin baik disiplin karyawan, semakin tinggi prestasi bagi organisasi perusahaan mencapai hasil yang optimal $^{1}$.

Kedisiplinan yang dikemukakan oleh Hasibuan (2011) merupakan salah satu model sikap yang dapat digunakan mengetahui kedisiplinan seorang pimpinan dalam menyikapi faktor-faktor yang mempengaruhi kedisiplinan pegawai di Puskesmas Kawatuna. Adapun komponen yang menggambarkan sikap seorang pimpinan tersebut adalah teladan pimpinan, keadilan, waskat, ketegasan, sanksi hukuman dan hubungan kemanusiaan. kedisiplinan juga merupakan kesadaran dan kesediaan seseorang yang menaati semua peraturan dan norma-norma sosial yang berlaku. Disiplin yang mencerminkan besarnya rasa tanggung jawab seseorang terhadap tugas-tugas yang diberikan kepadanya. Hal ini mendorong gairah kerja, semangat kerja, dan terwujudnya tujuan yang ingin dicapai.

Peningkatan sikap disiplin sangat penting untuk pertumbuhan organisasi, terutama untuk memotivasi pegawai agar dapat mendisiplinkan diri dalam melaksanakan pekerjaan, baik secara perorangan maupun kelompok. Sebagaimana yang tertuang dalam keputusan Badan Kepegawaian Negara Nomor 21 Tahun 2010 tentang Ketentuan Pelaksanaan Peraturan Pemerintah Nomor 53 Tahun 2010 tentang Disiplin Pegawai Negeri Sipil. Disiplin Pegawai Negeri Sipil adalah kesanggupan untuk menaati kewajiban dan menghindari larangan yang ditentukan dalam peraturan perundang-undangan dan/atau peraturan kedinasan yang apabila tidak ditaati atau dilanggar akan dijatuhi hukuman disiplin 2 .

Puskesmas adalah unit pelaksana teknis dinas kesehatan kabupaten/kota yang menyelenggarakan pembangunan kesehatan di suatu wilayah kerja. Puskesmas sebagai ujung tombak sistem pelayanan kesehatan nasional mempunyai peranan yang sangat besar dan strategis dalam meningkatkan derajat kesehatan masyarakat. Puskesmas bertanggung jawab menyelenggarakan pelayanan kesehatan tingkat pertama secara menyeluruh, terpadu dan berkesinambungan. Kinerja dari puskesmas sangat dipengaruhi ketersediaan sumber daya manusia yang dimiliki, terutama ketersediaan tenaga kesehatan. Pembangunan kesehatan yang diselenggarakan di puskesmas mendukung terwujudnya kecamatan sehat. Dalam mencapai tujuan pembangunan kesehatan di tingkat kecamatan, puskesmas dipimpin oleh kepala puskesmas ${ }^{3}$.

$\begin{array}{ccc}\text { Keberhasilan program } & \text { Puskesmas } \\ \text { sangat tergantung pada kemampuan }\end{array}$ pemimpinnya dalam mendisiplin bawahannya. Dengan kemampuan yang dimiliki oleh seorang pemimpin dapat mempengaruhi kinerja bawahan untuk melakukan pekerjaan sesuai dengan visi dan misi yang telah ditetapkan Puskesmas. Tuntutan pada masa kini mengharuskan organisasi dan orang yang terlibat di dalamnya bekerja dengan integritas yang tinggi. Begitu pula dengan organisasi pelayanan kesehatan yakni Puskesmas. Upaya peningkatan kinerja tenaga kesehatan menuntut peran seorang kepala puskesmas dalam melakukan pendekatan kepemimpinan yang efektif, keberhasilan Puskesmas sangat 
tergantung pada kemampuan pemimpinnya. Cara pandang setiap bawahan terhadap pemimpinnya akan berbeda antara satu dengan lainnya, persepsi individu terhadap kepemimpinan akan berpengaruh pada perilaku mereka dalam bekerja.

Salah satu unit organisasi yang dibawahi oleh seorang pemimpin yaitu puskesmas. Puskesmas merupakan unit pelaksanaan teknis dinas kesehatan kabupaten atau kota yang bertanggung jawab menyelenggarakan pembangunan kesehatan di suatu wilayah kerja. Menurut PERMENKES RI Nomor 75 tahun 2014 Pusat Kesehatan Masyarakat yang selanjutnya disebut Puskesmas adalah fasilitas pelayanan kesehatan yang menyelenggarakan upaya kesehatan masyarakat dan upaya kesehatan perseorangan tingkat pertama, dengan lebih mengutamakan upaya promotif dan preventif, untuk mencapai derajat kesehatan masyarakat yang setinggi-tingginya di wilayah kerjanya ${ }^{4}$.

Kota Palu memiliki 13 Puskesmas yang tersebar di 13 wilayah Kecamatan. Berdasarkan data Dinas Kesehatan Kota, dari 13 puskesmas, Puskesmas Kawatuna merupakan salah satu puskesmas yang masih kurang kedisiplinannya mengenai waktu keterlambatan dan absensi. Puskesmas Kawatuna memiliki tenaga kesehatan dan non kesehatan sebanyak 64 orang. Lebih rincinya tenaga kesehatan PNS berjumlah 42 orang, yang terdiri dari tenaga kesehatan 40 orang, non kesehatan 2 orang. Pegawai tidak tetap (PTT) berjumlah 4 orang, tenaga kesehatan kontak berjumlah 5 orang. Dan tenaga kesehatan yang mengabdi berjumlah 13 orang.

Berdasarkan hasil studi pendahuluan yang dilakukan di Puskesmas Kawatuna didapatkan informasi bahwa pada tahun 2019 rekapitulasi absen diperoleh data absensi sebagian dari pegawai masih melakukan tindakan tidak disiplin, yaitu sekitar 18 dari 64 orang yang sering izin diluar dari tugas luar (TL), tugas belajar (TB) dan sering terlambat datang. Hal tersebut menggambarkan kedisiplinan pegawai di Puskesmas Kawatuna masih cenderung kurang dan hal ini mempengaruhi tingkat kedisiplinan pegawai lainnya, serta dapat menghambat proses pelayanan kesehatan di Puskemas.

Informasi yang didapatkan dari wawancara dengan Kepala Puskesmas menyatakan bahwa masih terdapat beberapa pegawai yang kurang disiplin, contohnya terkait masalah keterlambatan. Pada aspek kehadiran di Puskesmas, masih banyak pegawai yang hadir tidak sesuai dengan jadwal yang telah ditetapkan. Hal ini biasanya dikarenakan kendala mengantar anak sekolah, mengurus keluarga, ataupun ada masalah lain yang membuat terlambat. Sanksi yang diberikan oleh kepala Puskesmas kepada pegawainya yang masuk kerja tidak tepat waktu atau tidak masuk kerja tanpa keterangan adalah, teguran lisan, pemotongan jasa, dan surat teguran.

Berdasarkan latar belakang di atas, maka peneliti tertarik untuk melakukan penelitian dengan faktor-faktor yang mempengaruhi kedisiplinan pegawai di puskesmas kawatuna Kota Palu.

\section{METODE PENELITIAN}

Jenis penelitian ini adalah penelitian kuantitatif dengan desain Cross Sectional Study, yakni suatu penelitian yang bertujuan untuk melihat suatu pengaruh pada variabelvariabel independen dan variabel dependen, dengan mengukur faktor-faktor yang mempengaruhi kedisiplinan pegawai Puskesmas Kawatuna Kota Palu. Studi dilakukan untuk menganalisis hubungan antara variabel independen (teladan pimpinan, keadilan, waskat, ketegasan, sanksi hukuman, dan hubungan kemanusiaan) dengan variabel dependen (kedisiplinan). 


\section{HASIL DAN PEMBAHASAN}

Adapun hasil dan pemabahasan dalam penelitian adalah :

\section{A. Analisis Univariat}

Berdasarkan hasil analisi univariat terkait identitas responden diketahui bahwa kelompok umur terbanyak pada responden yaitu kelompok umur 27-31 tahun sebanyak 15 orang $(23,5 \%)$, sedangkan yang paling sedikit yaitu kelompok umur 47-51 tahun sebanyak 2 orang $(3,1 \%)$. Hal ini didukung teori Harjowinoto (2008), usia produktif biasanya berkisar antara 20-40 tahun. Di usia produktif biasanya kita berada pada kondisi prima yaitu memberikan pelayanan public yang berkualitas. Dengan jumlah usia produktif yang ada dapat menjadi dasar bagi puskesmas untuk meningkatkan kualitas pelayanan.

Jenis kelamin responden terbanyak yaitu perempuan sebanyak 57 orang $(89,1 \%)$, sedangkan laki-laki sebanyak 7 orang $(10,9 \%)$. Hal ini didukung oleh teori Notoatmodjo (2003). Bahwa profesi keperawatan merupakan profesi yang dipandang lebih cocok untuk para perempuan ketimbang laki-laki, dikarenakan kelebihan perempuan atas lakilaki secara kodrati adalah kepekaan dan emosi mereka. Perempuan secara tabiat lebih intuitif (lebih peka) daripada pria. Dengan demikian, sebagai suatu pekerjaan yang didasarkan atas naluri, keperawatan banyak didominasi oleh perempuan ${ }^{5}$.

Pendidikan responden terbanyak yaitu D3 sebanyak 49 orang (76,6\%), sedangkan S1 sebanyak 15 orang $(23,4 \%)$. Hal ini didukung oleh teori Nursalam (2012), bahwa pendidikan merupakan hal yang sangat perlu diperhatikan oleh setiap instansi dalam usaha meninggkatkan keterampilan dan keahlian tenaga kerja, sebagai pengembangan karyawan. Karena semakin tinggi pendidikan seseorang maka akan semakin tinggi pula pengetahuan yang ia miliki ${ }^{6}$.

Dan masa kerja 1-5 tahun sebanyak 28 orang $(43,8)$, sedangkan responden yang paling sedikit memiliki masa kerja 26-31 tahun sebanyak 5 orang $(7,9 \%)$. Hal ini didukung oleh teori Netisemito (2003), bahwa dalam melakukan pekerjaan, faktor lingkungan kerja memeang peran yang penting karena merupakan hal yang terdekat dengan teman kerja dan semakin banyak masa kerja pegawai maka semakin banyak pengalaman pegawai tersebut dalam memberikan pelayanan kesehatan yang sesuai dengan standar atau prosedur ${ }^{7}$.

\section{B. Analisis Bivariat}

\section{Hubungan Teladan Pimpinan dengan Kedisiplinan Pegawai di Puskesmas Kawatuna}

Teladan pimpinan sangat berperan dalam menentukan kedisiplinan karyawan. Pimpinan harus memberi contoh yang baik, berdisiplin baik, jujur, adil, serta sesuai kata dengan perbuatan. Dengan teladan pimpinan yang baik, kedisiplinan bawahan pun akan baik. Jika teladan pimpinan kurang baik (kurang berdisiplin), para bawahan pun akan kurang disiplin ${ }^{8}$.

Tabel 5.14 menunjukan bahwa responden yang menganggap teladan pimpinan kurang baik dan kurang disiplin yaitu sebanyak 32 responden $(88,9 \%)$. Hal ini disebabkan kepala puskesmas kurang bersosialisasi dan berinteraksi pada bawahannya.

Hasil penelitian juga menunjukan bahwa responden yang menganggap teladan pimpinan kurang baik namun disiplin yaitu sebanyak 4 responden $(11,1 \%)$. Hal ini dikarenakan pimpinan memberikan tugas sesuai dengan tupoksi pegawai masing-masing. 


\begin{abstract}
Hasil penelitian ini juga
menunjukan bahwa responden yang menganggap teladan pimpinan baik namun kurang disiplin yaitu sebanyak 9 responden $(67,9 \%)$. Hal ini dikarenakan pimpinan memberikan contoh yang baik, dan datang tepat waktu.

Penelitian ini juga menunjukan pada responden yang menganggap teladan pimpinan baik dan disiplin sebanyak 23 responden $(32,1 \%)$.

Hal ini dikarenakan pimpinan memberikan tingkah laku yang patut di contoh, bersikap ramah, dan dapat dijadikan panutan terhadap pegawainya.

Hal ini didukung dengan teori yang di kemukakan oleh Hasibuan (2008), bahwa teladan pimpinan sangat berperan dalam menentukan kedisiplinan pegawai karena pimpinan dijadikan teladan dan panutan oleh para bawahannya. Dengan teladan pimpinan yang baik, kedisiplinan bawahan pun akan ikut baik. Tetapi jika teladan pimpinan kurang baik (kurang disiplin), para bawahan pun pasti akan kurang disiplin ${ }^{9}$.
\end{abstract}

Berdasarkan hasil analisis menggunakan uji Chi Square yang dilakukan terhadap keteladanan pimpinan pegawai, didapatkan hasil nilai $\rho=0,000$ sehingga $\rho<0,05$ maka hipotesis alternatif pada penelitian ini diterima, artinya bahwa ada hubungan teladan pimpinan dengan kedisiplinan di Puskesmas Kawatuna Kota Palu dilihat dari hasil olah data pada indikator datang tepat waktu, disiplin, dan memberikan contoh yang baik.

Hasil penelitian ini sejalan dengan hasil penelitian yang di kemukakan oleh Hidayat (2015), menunjukan bahwa teladan pimpinan berpengaruh secara simultan terhadap disiplin kerja pegawai Dinas Pendapatan
Daerah Provinsi Kalimantan Timur ${ }^{10}$. Penelitian Anwar (2010), menunjukan bahwa teladan pimpinan berpengaruh signifikan terhadap disiplin kerja Pegawai Dinas Pekerjaan Umum Kabupaten Kutai Timur ${ }^{11}$.

Hasil penelitian ini juga sejalan dengan hasil penelitian Dwi Umar Said Herman (2020), menunjukan bahwa ada hubungan teladan pimpinan dengan disiplin kerja karyawan $(p=0,006)$. Hal itu disebabkan pimpinan memberikan contoh yang baik, jujur, adil, serta sesuai kata dengan perbuatan. Sehingga meningkatkan sikap disiplin pegawai ${ }^{12}$.

Hasil penelitian ini tidak sejalan dengan hasil penelitian Sandi (2013), tidak ada hubungan yang signifikan antara teladan pimpinan dengan disiplin kerja Pegawai Dinas Kesehatan di Kabupaten Nagan Raya. Setelah dilakukan uji statistik Chi square pada derajat kepercayaan (konfidience Level) $95 \%(\alpha=0,05)$ diperoleh nilai $\mathrm{p}=0,709$ (p>0,05), maka Ha ditolak ${ }^{13}$.

\section{Hubungan Keadilan dengan}

\section{Kedisiplinan Pegawai di Puskesmas}

\section{Kawatuna}

Keadilan ikut mendorong terwujudnya kedisiplinan karyawan, keadilan yang dijadikan dasar kebijaksanaan dalam pemberian balas jasa (pengakuan) atau hukuman, akan merangsang terciptanya kedisiplinan pegawai yang baik. Dengan keadilan yang baik akan menciptakan kedisiplinan yang baik pula ${ }^{8}$.

Tabel 5.15 menunjukan bahwa responden yang menganggap keadilan kurang adil dan kurang disiplin yaitu sebanyak 29 responden $(85,3 \%)$. Hal ini dikarenakan pegawai menganggap pimpinannya bersikap tidak adil dalam hal memberikan beban kerja. 


Hasil penelitian ini juga
menunjukan bahwa responden yang
menganggap kurang adil namun disiplin
yaitu sebanyak 5 responden $(14,7 \%)$.
Hal ini disebabkan pimpinan akan
memberikan sanksi pada bawahan
apabila mereka tidak menjalankan tugas
sesuai dengan tupoksinya masing-
masing.

Hasil penelitian ini juga menunjukan bahwa responden yang menganggap adil namun kurang disiplin yaitu sebanyak 12 responden $(40,0 \%)$. Hal ini dikarenakan pegawai menyatakan bahwa pimpinannya memperlakukan bawahannya tanpa membedakan pangkat atau golongan.

Hasil penelitian ini juga menunjukan bahwa responden yang menganggap adil dan disiplin sebanyak $(60,0 \%)$. Hal ini dikarenakan pegawai menyatakan pimpinannya bersikap adil dalam memberikan tugas dan tidak membeda-bedakan pangkat atau golongan setiap pegawainya.

Hal ini didukung dengan teori yang di kemukakan oleh Hasibuan (2005), keadilan yang dijadikan dasar kebijaksanaan dalam pemberian balas jasa (pengakuan) atau hukuman, akan merangsang terciptanya kedisiplinan pegawai yang baik. Pimpinan yang cakap dalam memimpin selalu berusaha bersikap adil terhadap semua bawahannya. Dengan keadilan yang baik, akan menciptakan kedisiplinan yang baik pula ${ }^{14}$.

Berdasarkan hasil analisis menggunakan uji Chi Square yang dilakukan terhadap keadilan dengan kedisiplinan pegawai, didapatkan hasil nilai $\rho=0,000$ sehingga $\rho<0,05$ maka hipotesis alternatif pada penelitian ini diterima, artinya bahwa ada hubungan keadilan dengan kedisiplinan di
Puskesmas Kawatuna Kota Palu dilihat dari hasil olah data pada indicator adil dalam memberikan tugas, tidak membeda-bedakan pangkat ataupun golongan.

Hasil penelitian ini sejalan dengan penelitian Falaq (2015), ada hubungan yang signifikan antara keadilan dengan disiplin kerja perawat di RS. Dr. Tadjuddin Chalid Makassar ${ }^{15}$. Hasil penelitian ini juga sejalan dengan hasil penelitian Sandi (2013), ada hubungan yang signifikan antara keadilan dengan disiplin kerja Pegawai Dinas Kesehatan di Kabupaten Nagan Raya ${ }^{13}$. Karena kepemimpinan yang dilaksanakan di RS. Dr. Tadjuddin Chalid Makassar diselenggarakan dengan memberikan keadilan dan kesempatan yang seluasluasnya dalam setiap kesempatan untuk pengembangan karir perawat.

Hasil penelitian ini juga sejalan dengan hasil penelitian Alibar (2008), bahwa ada hubungan yang signifikan antara keadilan dengan disiplin karyawan. Keadilan yang dijadikan dasar kebijakan dalam pemberian balas jasa, pengakuan maupun hukuman akan merangsang terciptanya kedesiplinan karyawan yang baik. Keadilan ikut mendorong terwujudnya kedisiplinan karyawan, karena ego dan sifat manusia yang selalu merasa dirinya penting dan ingin diperlakukan sama dengan manusia lainnya ${ }^{16}$.

\section{Hubungan Pengawasan Melekat dengan Kedisiplinan Pegawai di Puskesmas Kawatuna}

Waskat (pengawasan melekat) adalah tindakan nyata dan paling efektif dalam mewujudkan kedisiplinan karyawan. Dengan waskat berati atasan harus aktif dan langsung mengawasi perilaku, moral, sikap, 
gairah kerja, dan prestasi kerja bawahannya. Hal ini berarti atasan harus selalu ada/hadir ditempat kerja agar dapat mengawasi dan memberikan petunjuk, jika ada bawahannya yang mengalami kesulitan menyelesakan pekerjaannya $^{8}$.

Tabel 5.16 menunjukan bahwa responden yang menganggap pengawasan melekat kurang baik dan kurang disiplin yaitu sebanyak 29 responden $82,9 \%$. Hal ini dikarenakan pegawai menyatakan pimpinannya tidak pernah mengawasi pekerjaan pegawainya, dan tidak pernah memberikan apresiasi terhadap pekerjaan pegawainya.

Hasil penelitian ini juga menunjukan bahwa responden yang menganggap pengawasan melekat kurang baik namun disiplin yaitu sebanyak 6 responden $(17,1 \%)$. Hal ini dikarenakan pegawai mendapatkan pengawasan yang aktif dari pimpinannya, serta mendengarkan kekhawatiran pegawai sebelum keputusan tentang pekerjaan dibuat.

Hasil penelitian ini juga menunjukan bahwa responden yang menganggap pengawasan melekat baik namun kurang disiplin yaitu sebanyak 12 responden $(41,4 \%)$. Hal ini dikarenakan pegawai menyatakan bahwa pimpinannya selalu melakukan evaluasi berkala setiap bulannya utnuk mengetahui permasalahan dan hambatan pegawai dalam menyelesaikan tugasnya.

Hasil penelitian ini juga menunjukan bahwa responden yang menganggap pengawasan melekat baik dan disiplin yaitu sebanyak 17 responden (58,6\%). Hal ini dikarenakan pimpinan selalu melakukan pengawasan yang aktif terhadap kinerja pegawainya.

Hal ini didukung dengan teori yang dikemukakan oleh Hasibuan (2007), dengan waskat, atasan secara langsung dapat mengetahui kemampuan dan kedisiplinan setiap individu bawahannya, sehingga kondisi setiap bawahan dinilai objektif. Waskat bukan hanya mengawasi moral kerja dan kedisiplinan karyawan saja, tetapi juga harus berusaha mencari sistem kerja yang lebih efektif untuk mewujudkan tujuan organisasi, karyawan, dan masyarakat. Dengan sistem yang baik akan tercipta internal kontrol yang mengurangi kesalahankesalahan dan mendukung kedisiplinan serta moral kerja karyawan ${ }^{8}$.

Berdasarkan hasil analisis menggunakan uji Chi Square yang dilakukan terhadap pengawasan melekat dengan kedisiplinan pegawai, didapatkan hasil nilai $\rho=0,000$ sehingga $\rho<0,05$ maka hipotesis alternatif pada penelitian ini diterima, artinya bahwa ada hubungan pengawasan melekat dengan kedisiplinan di Puskesmas Kawatuna Kota Palu dilihat dari hasil olah data pada indikator pengawasan yang aktif, melakukan evaluasi berkala, dan mendengarkan kekhawatiran pegawai sebelum keputusan tentang pekerjaan dibuat.

Hasil penelitian ini sejalan dengan hasil penelitian yang dikemukakan oleh Dwi Umar Said Herman (2020), Wakskat berpengaruh signifikan positif terhadap disiplin kerja karyawan PT. Skatindo Sarana Acara Yogyakarta ${ }^{12}$. Hasil penelitian ini juga sejalan dengan penelitian Sandi (2013), ada hubungan yang signifikan antara waskat dengan 


\begin{tabular}{|c|}
\hline $\begin{array}{lcrr}\text { disiplin } & \text { kerja } & \text { Pegawai } & \text { Dinas } \\
\text { Kesehatan } & \text { di } & \text { Kabupaten } & \text { Nagan } \\
\text { Raya }^{13} \text {. } & & & \end{array}$ \\
\hline $\begin{array}{l}\text { Pengawasan melekat efektif } \\
\text { merangsang kedisiplinan dan moral } \\
\text { kerja karyawan. karyawan merasa } \\
\text { mendapat perhatian, bimbingan, } \\
\text { petunjuk, pengarahan dan pengawasan } \\
\text { dari atasannya. Jadi, pengawasan } \\
\text { melekat menuntut adanya kebersamaan } \\
\text { aktif antara atasan dengan bawahan } \\
\text { dalam mencapai tujuan yang telah } \\
\text { ditentukan sebelumnya. }\end{array}$ \\
\hline $\begin{array}{l}\text { Hasil penelitian ini tidak sejalan } \\
\text { dengan penelitian Falaq (2015) ,tidak } \\
\text { ada hubungan antara pengawasan } \\
\text { melekat dengan disiplin kerja perawat } \\
\text { di RS. Dr. Tadjuddin Chalid Makassar. } \\
\text { Adapun hasil uji statistik Chi-Square } \\
\text { nilai p }=0,135 \text { dengan } \alpha=0,05 \text { artinya } \\
\text { probabilitas lebih besar dari } \alpha \\
(0,135>0,05)^{15} \text {. }\end{array}$ \\
\hline
\end{tabular}

\section{Hubungan Sanksi Hukuman dengan} Disiplin Kerja Pegawai di Puskesmas Kawatuna

Berat/ ringannya sanksi hukuman yang akan diterapkan ikut mempengaruhi baik/buruknya kedisiplinan karyawan. Sanksi human harus diterapkan berdasarkan pertimbangan logis, masuk akal, dan diinformasikan secara jelas kepada semua karyawan.

Sanksi hukuman seharusnya tidak terlalu ringan atau terlalu berat supaya hukuman itu tetap mendidik karyawan untuk mengubah perilakunya. Sanksi hukuman hendaknya cukup wajar untuk setiap tingkatan yang indisipliner, bersifat mendidik, dan menjadi alat motivasi untuk memelihara kedisiplinan ${ }^{8}$.

Tabel 5.17 menunjukan bahwa responden yang menganggap sanksi hukuman kurang tegas dan kurang disiplin yaitu sebanyak 16 responden $(55,2 \%)$. Hal ini dikarenakan ketika pegawai melakukan kesalahan dan terlambat dalam mengumpulkan tugas sesuai dengan jadwal yang telah ditentukan dalam pekerjaannya maka akan mendapatkan sanksi hukuman.

Hasil penelitian ini juga menunjukan bahwa responden yang menganggap sanksi hukuman kurang tegas dan disiplin yaitu sebanyak 13 responden (44,8\%). Hal ini dikarenakan pegawai tidak melihat sanksi yang ada, tetapi mereka mengerjakan tugasnya sesuai dengan tupoksinya masing masing, serta mengumpulkan semua tugas sesuai dengan jadwal yang telah ditentukan.

Hasil penelitian ini juga menunjukan bahwa responden yang menganggap sanksi hukuman tegas namun kurang disiplin yaitu sebanyak 25 responden $(71,4 \%)$. Hal ini dikarenakan sanksi hukuman yang diberikan sesuai dengan kesalahan yang dilanggar, dan jika melakukan kesalahan yang sangat fatal maka pimpinan memberikan sanksi hukuman berupa SP 1.

Hasil penelitian ini juga menunjukan bahwa responden yang menganggap sanksi hukuman tegas dan disiplin yaitu sebanyak 10 responden $10 \quad(28,6 \%)$. Hal ini dikarenakan pimpinan akan memberikan sanksi dan proses hukumannya diserahkan pada badan kepegawaian daerah apabila dalam pekerjaannya melakukan kesalahan yang sangat fatal.

Hal ini didukung oleh teori yang di kemukakan oleh Hasibuan (2007), Sanksi hukuman berperan penting dalam memelihara kedisiplinan pegawai, karena melalui sanksi 
hukuman yang semakin berat, pegawai akan semakin takut melanggar peraturan-peraturan yang ada, serta sikap dan perilaku indisipliner pegawai yang berkurang ${ }^{8}$.

Berdasarkan hasil analisis menggunakan uji Chi Square yang dilakukan terhadap sanksi hukman dengan kedisiplinan pegawai, didapatkan hasil nilai $\rho=1,81$ sehingga $\rho>0,05$ maka hipotesis alternatif pada penelitian ini diterima, artinya bahwa tidak ada hubungan sanksi hukuman dengan kedisiplinan di Puskesmas Kawatuna Kota Palu dilihat dari hasil olah data pada indikator sanksi hukuman yang diberikan sesuai dengan kesalahan yang dilanggar, melakukan kesalahan dan terlambat dalam mengumpulkan tugas sesuai dengan jadwal yang telah ditentukan maka akan dikenakan sanksi hukuman, dan megerjakan tugas sesuai dengan tupoksinya masing-masing.

Hasil penelitian ini sejalan dengan hasil penelitian Falaq (2015), Berdasarkan hasil uji statistik ChiSquare nilai $p=0,550$ dengan $\alpha=0,05$ artinya probabilitas lebih besar dari $\alpha$ $(0,550>0,05)$, maka tidak ada hubungan antara pemberian sanksi dengan disiplin kerja perawat di RS. Dr. Tadjuddin Chalid Makassar ${ }^{15}$. Hasil penelitian ini juga sejalan dengan hasil penelitian Sandi (2013), tidak ada hubungan yang signifikan antara sanksi dengan disiplin kerja Pegawai Dinas Kesehatan di Kabupaten Nagan Raya $^{13}$.

Hasil penenlitian ini tidak sejalan dengan hasil penelitian Dwi Umar Said Herman (2020), menunjukkan bahwa variabel sanksi/hukuman terhadap karyawan berpengaruh signifikan positif terhadap disiplin kerja karyawan PT. Skatindo Sarana Acara Yogyakarta ${ }^{12}$. Hal ini ditunjukkan oleh keseluruhan nilai signifikansi $t$ hitung sebesar $0.032<0.05$. karena Berat/ringannya sanksi hukuman yang akan diterapkan ikut mempengaruhi baik/buruknya kedisiplinan karyawan.

5. Hubungan Ketegasan dengan Kedisiplinan Pegawai di Puskesmas Kawatuna

Ketegasan pimpinan dalam
melakukan tindakan
akan
mempengaruhi kedisiplinan karyawan.
Pimpinan harus berani dan tegas,
bertindak untuk menghukum setiap
karyawan yang indisipliner sesuai
dengan sanksi hukuman yang telah
ditetapkan. Ketegasan pimpinan
menegur dan menghukum setiap
karyawan yang indisipliner akan
mewujudkan kedisiplinan yang baik
pada instansi ${ }^{8}$.

Tabel 5.18 menunjukan bahwa responden yang menganggap kurang tegas dan kurang disiplin yaitu sebanyak 13 responden $(92,9 \%)$. Hal ini dikarenakan pimpinan kurang tegas dalam menerapkan hukuman berupa sanksi kepada pegawainya.

Hasil penelitian ini juga menunjukan bahwa responden yang menganggap kurang tegas namun disiplin yaitu sebanyak 1 responden $7,1 \%$. Hal ini dikarenakan pimpinan menggunakan nada bicara yang tegas dalam berkomunikasi serta bertindak untuk memberikan sanksi pada pegawai yang tidak disiplin.

Hasil penelitian ini juga menunjukan bahwa responden yang menganggap tegas namun kurang disiplin yaitu sebanyak 28 responden $(56,0 \%)$. Hal ini dikarenakan pimpinannya bersikap tegas kepada 
pegawainya dan memberikan sanksi sesuai dengan kesepakatan bersama.

Hasil penelitian ini juga menunjukan bahwa responden yang menganggap tegas dan disiplin yaitu sebanyak 22 responden $(44,0 \%)$. Hal ini dikarenakan pimpinannya bertindak tegas dalam menerapkan hukuman atau sanksi kepada pegawainya apabila pegawai melakukan kesalahan dalam menjalankan tugasnya, serta menggunakan nada bicara yang tegas dalam berkomunikasi dengan pegawai.

Hal ini didukung dengan teori yang dikemukakan oleh Hasibuan (2005), Pimpinan harus berani dan tegas bertindak untuk menghukum setiap pegawai yang indisipliner sesuai dengan sanksi hukuman yang telah ditetapkan. Pimpinan yang berani menindak tegas menerapkan hukuman bagi pegawai yang indisipliner akan disegani dan diakui kepemimpinannya oleh bawahannya. Dengan demkian, pimpinan akan memelihara kedisiplinan pegawai ${ }^{14}$.

Berdasarkan hasil analisis menggunakan uji Chi Square yang dilakukan terhadap ketegasan dengan kedisiplinan pegawai, didapatkan hasil nilai $\rho=0,012$ sehingga $\rho<0,05$ maka hipotesis alternatif pada penelitian ini diterima, artinya bahwa ada hubungan ketegasan dengan kedisiplinan di Puskesmas Kawatuna Kota Palu dilihat dari hasil olah data pada indikator menggunakan nada bicara tegas pada saat berkomunikasi, bersikap tegas dan bertindak tegas dalam menerapkan sanksi hukuman.

Hasil penelitian ini sejalan dengan penelitian Ahadiyah (2009) bahwa terdapat hubungan yang signifikan antara ketegasan pimpinan dengan kedisiplinan kerja pegawai di
Pelayanan Bea Cukai Malang ${ }^{17}$. Hal senada juga terungkap dari penelitian Alibar (2008) bahwa ada pengaruh yang signifikan antara ketegasan terhadap kedisiplinan pegawai ${ }^{16}$. Hasil penelitian ini juga sejalan dengan hasil penelitian Sandi (2013), ada hubungan yang signifikan antara ketegasan dengan disiplin kerja Pegawai Dinas Kesehatan di Kabupaten Nagan Raya $^{13}$. Seorang pimpinan harus berani dan tegas bertindak untuk menghukum setiap karyawan yang tidak disiplin sesuai dengan sanksi atau hukuman yang telah ditetapkan. Sebaliknya, apabila seorang pimpinan kurang tegas dan tidak menghukum karyawan yang tidak disiplin, maka sulit baginya untuk memelihara kedisiplinan bawahannya bahkan sikap kurang disiplin karyawan semakin banyak, karena mereka beranggapan bahwa peraturan dan sanksi atau hukuman tidak berlaku lagi

Hasil penelitian ini tidak sejalan dengan hasil penelitian Falaq (2015), tidak ada hubungan yang bermakna antara ketegasan pimpinan dengan disiplin kerja perawat di RS. Dr. Tadjuddin Chalid Makassar. Adapun hasil uji statistik Chi-Square nilai $\mathrm{p}=$ 0,140 dengan $\alpha=0,05$ artinya probabilitas lebih besar dari $\alpha$ $(0,140>0,05)^{15}$.

6. Hubungan Kemanusiaan dengan Kedisiplinan Pegawai di Puskesmas Kawatuna

Hubungan kemanusiaan yang harmonis diantara sesama pegawai ikut menciptakan kedisiplinan yang baik pada suatu instansi dan akan memotivasi kedisiplinan yang baik. sehingga kedisiplinan pegawai akan tercipta apabila hubungan kemanusiaan dalam organisasi tersebut baik. 
Tabel 5.19 menunjukan bahwa responden yang menganggap hubungan kemanusian kurang baik dan kurang disiplin yaitu sebanyak 35 responden (89,7\%). Hal ini dikarenakan pegawai menyatakan pimpinan kurang bersikap harmonis dan kurang berinteraksi kepada pegawainya.

Hasil penelitian ini juga menunjukan bahwa responden yang menganggap hubungan kemanusiaan kurang baik namun disiplin yaitu sebanyak 4 responden $(10,3 \%)$. Hal ini dikarenakan adanya sikap saling menghormati dan menghargai antara pegawai dan pimpinan.

Hasil penelitian ini juga menunjukan bahwa responden yang menganggap hubungan kemanusiaan baik namun kurang disiplin yaitu sebanyak 6 responden $(24,0 \%)$. Hal ini dikarenakan pimpinan memiliki hubungan yang baik dengan pegawai, serta pimpinan memperlakukan pegawainya sesuai dengan hak dan kemanusiaan.

Hasil penelitian ini juga menunjukan bahwa responden yang menganggap hubungan kemanusiaan baik dan disiplin yaitu sebanyak 19 responden (76,0\%). Hal ini dikarenakan pimpinan dan pegawainya saling membantu dalam kesulitan melakukan pekerjaan, saling menyemangati secara profesional, memiliki kebersamaan yang aktif dan memiliki hubungan yang harmonis.

Hal ini didukung dengan teori yang di kemukakan oleh Hasibuan (2012), Hubungan kemanusiaan yang harmonis di antara sesama karyawan ikut menciptakan kedisiplinan yang baik pada suatu perusahaan ${ }^{18}$.
Berdasarkan hasil analisis menggunakan uji Chi Square yang dilakukan terhadap hubungan kemanusiaan dengan kedisiplinan pegawai, didapatkan hasil nilai $\rho=0,000 \quad$ sehingga $\rho<0,05$ maka hipotesis alternatif pada penelitian ini diterima, artinya bahwa ada hubungan kemanusiaan dengan kedisiplinan di Puskesmas Kawatuna Kota Palu dilihat dari hasil olah data pada indikator saling membantu dalam kesulitan melakukan pekerjaan, saling menyemangati secara profesional, memiliki kebersamaan yang aktif dan memiliki hubungan yang harmonis.

Hasil penelitian ini sejalan dengan hasil penelitian Sandi (2013), ada hubungan yang signifikan antara hubungan antar manusia dengan disiplin kerja Pegawai Dinas Kesehatan di Kabupaten Nagan Raya $^{13}$. Hasil penelitian ini juga sejalan dengan penelitian Alibar (2008) dimana terdapat pengaruh yang signifikan antara hubungan antar manusia terhadap disiplin kerja pegawai ${ }^{16}$. Demikian juga halnya dengan hasil penelitian Ahadiyah (2009) yang mengungkapkan bahwa ada hubungan yang signifikan antara hubungan kemanusiaan dengan disiplin kerja karyawan ${ }^{17}$. Pimpinan harus berusaha menciptakan suasana hubungan kemanusiaan yang serasi serta mengikat, vertikal maupun horizontal diantara semua bawahannya. Hubungan kemanusiaan yang harmonis diantara sesama karyawan ikut memotivasi dan menciptakan kedisiplinan yang baik bagi organisasi.

Hasil penelitian ini tidak sejalan dengan hasil penelitian Falaq (2015), Adapun hasil uji statistik Chi-Square nilai $\mathrm{p}=0,290$ dengan $\alpha=0,05$ artinya 
probabilitas lebih besar dari $\alpha$ $(0,290>0,05)$, maka tidak ada hubungan yang bermakna antara hubungan kemanusiaan dengan disiplin kerja perawat di RS. Dr. Tadjuddin Chalid Makassar ${ }^{15}$.

\section{KESIMPULAN}

Berdasarkan penelitian yang dilakukan di Puskesmas Kawatuna Kota Palu, hasil penelitian ini menunjukan bahwa:

1. Ada hubungan teladan pimpinan dengan kedisiplinan pegawai di Puskesmas Kawatuna Kota palu.

2. Ada hubungan keadilan dengan kedisiplinan pegawai di Puskesmas Kawatuna Kota Palu.

3. Ada hubungan pengawasan melekat dengan kedisiplinan pegawai di Puskesmas Kawatuna Kota Palu.

4. Tidak ada hubungan sanksi hukuman dengan kedisiplinan pegawai di Puskesmas Kawatuna Kota Palu.

5. Ada hubungan ketegasan dengan kedisiplinan pegawai di Puskesmas Kawatuna Kota Palu.

6. Ada hubungan kemanusian dengan kedisiplinan pegawai di Puskesmas Kawatuna Kota Palu.

\section{DAFTAR PUSTAKA}

1. Dr. Shilphy A. Octavia M p. Sikap Dan Kinerja Guru Profesional. Grub Penerbitan CV. Budi Utama; 2019.

2. Badan Kepegawaian Negara. Perka BKN No 21 Tahun 2010 Tentang Ketentuan Pelaksanaan Peraturan Pemerintah Nomor 53 Tahun 2010 Tentang Disiplin Pegawai Negeri Sipil. Published online 2010:214.

3. Depkes. Profil Kesehatan Indonesia Tahun 2013. Kementrian Kesehatan RI; 2014. http://www.kemkes.go.id

4. Permenkes. Peraturan Menteri Kesehatan RI No 75 tahun 2014. Lincolin Arsyad. Published online 2014.

5. Notoatmodjo S. Pengembangan Sumber Daya Manusia. PT. Rineka Cipta; 2003.
6. Nursalam. Manajemen Keperawatan: Aplikasi Dalam PraktikKeperawatan Profesional. 3rd ed. Salemba Medika; 2012.

7. Nitisemito AS. Manajemen Personalia. Ghalia; 2003.

8. Hasibuan MS. Manajemen Sumber Daya Manusia Perusahaan. PT. Bumi Aksa; 2007.

9. Hasibuan M. Manajemen Dasar, Pengertian, Dan Masalah. PT Bumi Aksara; 2008.

10. Hidayat M. Pengaruh Faktor - faktor Kedisiplinan Terhadap Prestasi Kerja Pegawai Dinas Pendapatan Daerah Provinsi Kalimantan Timur. 2015;2.

11. Anwar S. Faktor - Faktor yang Mempengaruhi Disiplin Kerja Pegawai Dinas Pekerjaan Umum Kabupaten Kutai Timur. 2010;1.

12. Dwi Umar Said Herman. Analisis FaktorFaktor Yang Mempengaruhi Kedisiplinan Kerja Pada Karyawan Analysis of Factors That Affect Work Discipline in Employees of Pt Skatindo in. 2020;8(1):70-78.

13. Sandi I. Faktor-faktor yang berhubungan dengan disiplin kerja petugas kesehatan di Dinas Kesehatan Kabupaten Nagan Raya. Published online 2013.

14. Hasibuan M. Manajemen Sumber Daya Manusia. PT. BumiAksara; 2005.

15. Falaq M. Faktor-Faktor Yang Mempengaruhi Disiplin Kerja Perawat Di RS. Dr. Tadjuddin Chalik Makassar.; 2015.

16. Alibar M. Faktor-Faktor yang Mempengaruhi Disiplin Kerja Pegawai pada Biro Kepegawaian Sekretariat Jenderal Departemen Hukum dan HAM RI. Published online 2008.

17. Ahadiyah. Pengaruh Disiplin Kerja terhadap Kinerja Karyawan pada Kantor Pengawasan dan Pelayanan Bea dan Cukai Tipe Madya Cukai Malang. Published online 2009.

18. Hasibuan M. Manajemen SDM. 13th ed. Bumi Aksara; 2012. 